\title{
Status of Maharaja of Manipur in British India Empire and Current Social Status Among Peers
}

\author{
Oinam Ghanashyam Khumancha* \\ Oinam Teresa ${ }^{* *}$
}

\begin{abstract}
Many writers claim that Kingdom of Manipur with varieties of its names is a continuous institution from by-gone many millennia. Currently there is a general assertion by legislatures and by general public that Meitei Tribe should not be in Scheduled Tribe list of India any more due to adoption of Hindu and glorious history of kinghood. This paper will try to examine the status of Maharaja of Manipur within the British India Empire and current social status among peers to verify the merit of those wishful thinkers.
\end{abstract}

Keywords: Manipur, Meitei Tribe, British, Burma, Scheduled List

\footnotetext{
* Central University of Gujarat - India. email: oinam.ghanashyam@cug.ac.in
}

** Central University of Gujarat - India. email: teresa.oinam@cug.ac.in 


\section{INTRODUCTION}

The titular Maharaja of Manipur was a legacy of once independent Kingdom of Manipur that exist Before Common Era (BCE) to 1949 C.E. (Common Era) with cessation briefly due the invasion of Burmese from time to time and incorporation to British India Empire's Princely State after the defeat of Manipur in 1891 C.E. Manipur was a free independent democratic constitutional monarchy from 1947-1949 C.E. On 15 October 1949, Manipur was annex or merged with Dominion of India (Republic of India), and legality of this amalgamation is still under debate in many circles. The Maharaja belong to small community called Meitei tribe, which also read as Meetei tribe, which is a brother tribe of Thangkhul, Kabui etc. The present titular Maharaja of Manipur, Leisamba Sanajaoba, who is also a Member of Parliament on many occasions, has express his desire to included Meitei Tribe on Scheduled Tribe list of India. He opines that as Meitei Tribe is a weaker community among the Indian Society therefore, some legal measures needed to protect this vulnerable community. Nevertheless, until now the State Government of Manipur fail to send a recommendation letter to the Government of India.

According to understanding of Supreme Court of India, "the Scheduled Tribes are the indigenous people of India and these indigenous people need some legal safeguard". However, people like Ngairangbam Samarjit of NEIDP (North East India Development Party) express his disapproval of Meitei Tribes' demand of to be in Scheduled Tribe list of India, citing that Manipur kingdom used to have imperialistic character. Large number of public do not agree with his viewpoint. This paper will examine the status of Maharaja of Manipur using a historical method by reexamining colonial explorer writings and research work conducted by various scholars.

\section{Status of Maharaja of Manipur as a protectorate of British India}

Colonial McCulloch a political agent at Manipure, in his book "Account of the Valley of Munnipore and the Hill tribes: with a comparative vocabulary of the Munnipore and other languages" wrote that as far as his understanding goes, the Meitei Tribes is made up of Koomul tribes (Khuman), Looang tribes (Luwang), Moirang tribes and Meitei tribes. Khuman tribes were related to Marings tribes, Moirang tribes were related to old Kukis, Luwang and Meiteis tribes are related koupooees (Kabuis) tribes. ${ }^{1}$

In 1819 to become a king of Manipur, Marjeet took the help of Burmese King to defeat his brother Chourjeet Singh. Latter, Marjeet fail to send tribute to Burma, so to punish him Burmese Army invaded Manipur in 1819 and started 'Seven Years devastation' of Manipur. Marjeet seek refuge in Cachar where Chourjeet was already there. In 1823, the three-wannabe kings of Manipur i.e., Chourjeet, Marjeet and Gumbheer Singh went to Sylhet to meet with East India Company. They requested the military assistance of East India Company to fight Burmese Army and the protection against any future attack. The British Government permit the Gumbheer Singh to raise the Manipur Levy of 500 Manipuri's soldiers, but Gumbheer raise of number of soldiers to $2000 .^{2}$ This shows that the former Manipur's Kings fight for throne among themselves, which result other nation to invade their kingdom. Therefore, they had to seek protection from external powers. Their infighting makes it easy for others to occupy their territory and misruled over its

\footnotetext{
${ }^{1}$ William McCulloch, Account of the Valley of Munnipore and the Hill tribes: with a comparative vocabulary of the Munnipore and other languages" (1859) New Delhi : Akansha Publishing House, 2016 ,p.4

${ }^{2}$ Ibid.p. 8
} 
people. Even to regain their territory they have to become a protectorate kingdom of British Empire.

After the dead of Gumbheer Singh, his queen and Nur Sing yet again starts their infighting for throne. After the death of Nur Singh in 1850, Debendro Singh become the king, which Chandra Kitee Singh son of Gumbheer Singh opposed, and wage a war. Debendro was defeated and Chandra Kitee becomes the King but Debendro continued to wage war against Chandrakitee Singh from Cachar until the British Empire had enough of it and issued a warning against all who revolt against the King of Manipur. ${ }^{3}$ Manipur Kings has shown no maturity until British had enough of their family drama. Colonial McCulloch also observed that the Manipur King does not make any law; the only thing the king care is of his throne and the throne on his side his will is the paramount. ${ }^{4}$ This was the mentality of Manipur king, which is not of a responsible king. The British Empire feel letting Manipur by itself, is like to let something on chances, and Manipur was very important for the British India Empire to left it on luck. Therefore, the British India Empire appointed a British Officer as Political Agent to safeguard Manipur from future Burmese invasion. ${ }^{5}$ This shows that the British consider Manipur kings as incompetent rulers. Colonial McCulloch have contemplate that before King Chourajeet Singh, no king ever endorses any public work, which could benefit his subject. ${ }^{6}$

Around that time the British India Empire give Manipur's territory known as 'Kabo Valley' to Burma without consulting the King of Manipur, Gumbheer Singh who agreed with the British judgement without any thoughts for sum annual fees for that huge territory. This indicates that the Maharaja of Manipur have minimum values and authorities in eyes of the British Empire and in reality. In Major-General James Johnstone's book My Experiences in Manipur and Naga Hills, he stresses many times on the notion that Manipur's Maharaja need a good capable British Political Agent to govern Manipur and Manipur prosperity depended on the Maharaja loyalty to the British Government. ${ }^{7}$ In other words, the Maharaja of Manipur may be good, but a British officer will be always better than combine administrative structure of the King; and Manipur future is depended on the pleasure of British India Empire. This in a way, is complete dissing of the King of Manipur and the community he belongs i.e., Meitei Tribe and his subject. Still, the Major General does not view the current Maharaja or future potential Maharaja as capable rulers and they will always lack something.

James Johnstone observe that the Meitei King bloodline must be of Tangkhul origin as when the auspicious occasion of installation of the King, he and his Queen wears the dress of Tangkhul Tribes and ascend the throne; not only that the King's palace is made in the manner of Tangkhul's chief and guard by soldiers carring Tangkhul's weapons. ${ }^{8}$ This is what the current titular king, Leisamba Sanajaoba acknowledged on many occasions. The current titular king

\footnotetext{
${ }^{3}$ Ibid.,pp.9-11

${ }^{4}$ Ibid., p. 20

5 Ibid.,p.38

${ }^{6}$ Ibid., p.34

${ }^{7}$ M. G. Johnstone, My Experiences in Manipur and the Naga Hills. London: Sampson Low, Marston and Company Limited, 1896,p.24

${ }^{8}$ Ibid.
} 
believed the headman of Hungpung (a Tangkhul village) as his elder brother as Hungpung Khayaiwo (chief of Hungpung village) and the Meiteis share the same 'progenitor'.?

When Frank Grimwood appointed as British India Empire's Political Agent to the kingdom of Manipur in 1880s, his wife accompanies him. In 1886, his wife wrote a book, "My Three Years in Manipur and Escape from the Recent Mutiny". In that book, the author notice that when they are coming to Imphal for joining the post, 30 Manipuri King's Sepoys were send to guard them. They have only twelve clothes (uniform) which they wear when they are performing their duty in rotation. ${ }^{10}$ The lack of uniform for soldiers was observe during the peacetime. This indicates that to properly equip his soldiers there was acute shortage of funds in Maharaja Coffers.

\section{Status of Maharaja of Manipur in the British India}

After the Anglo-Manipur war of 1891, which in a way started due to infighting between the princes of Manipur, British India Empire incorporated Manipur as 'Princely State' within British India Empire. This again shows that ruling family of Manipur was not able to develop a stable structure to govern its own land. Based on the proclamation of British India Emperor George V of 23 December 1919, the Government of India Act 1919 was given royal assent and the 'Chamber of Princes' was established in 1920. ${ }^{11}$ It consisted of 120 members- of that 108 members were from more significant kingdoms and member on their own right. A conglomerate of 127 kingdoms represented the twelve seats and 327 minor kingdoms were left unrepresented. Some Maratha ruled Kingdoms like of Baroda, Gwalior and Holkar refused to join such Chamber. ${ }^{12}$ Between 1932-1936, Sir Chura Chand Singh, the Maharaja of Manipur applied for a seat in the Chamber of Princes and according to Chishti, the Maharaja of Manipur aware of the fact that his application will not be considered by the Chancellor of the Chamber and by the Viceroy of India. ${ }^{13}$ As Kingdom of Manipur might not be a prestigious or dignitary Kingdom in another word Kingdom of Manipur was a minor kingdom, which the other major kings and princes of India do not considered as equal or worthy. However, some of the major rulers who were included in the Chamber of Princes were Maharaja of Tripura, Sir Bir Bikram Kishore Manikya Deb Barman, Sir Tashi Namgyal, and King of Sikkim.

In his thesis title "Political Development in Manipur: 1919-1949", Dr. Chisti wrote that on 2 January 1937, the Maharaja of Manipur Sir Chur Chand and his son Priyobrata request the British India Empire to return the right to administrate the hill area of Manipur and Finance of Manipur to the Maharaja of Manipur which the British India bluntly denied. ${ }^{14}$ The Maharaja of Manipur was even ready to pay the full tribute i.e., Rs. 50,000/ instead of current tribute of Rs. $5000 /$ he has to pay being a poor State- only if he was accepted as a member of Chamber of

\footnotetext{
${ }^{9}$ Manipur: Titular king Leishemba Sanajaoba makes maiden visit to Ukhrul as MP. (2020, August 21). East Mojo, pp.https://www.eastmojo.com/news/2020/08/21/manipur-titular-king-leishemba-sanajaoba-makes-maiden-visit-toukhrul-as-mp/.

10 E.S. Grimwood, My Three Years in Manipur and Escape from the Recent Mutiny. London: Richard Bentley,1891,p.38

${ }^{11}$ B.N. Ramusack, The Princes of India in the Twilight of Empire: Dissolution of a Patron-client System, 19141939. Ohio: Ohio State University Press, 1978,p.xix

12 J. Allan, Haig, W., \& Dodwell, H. The Cambridge Shorter History of India. Cambridge: Cambridge University, 1969,p.1065

${ }^{13}$ S.Chisti, Political Development in Manipur, 1919-1949. Aligarh: Aligarh Muslim University, 1979, p.98

${ }^{14}$ Ibid.,pp.101-124
} 
Prince. The Financial power of Manipur was remove from Maharaja of Manipur after 1891 Anglo-Manipur War as a form of punishment for defiance against the mighty British Empires. Moreover, the administration of hill area was take away after the event of Kuki rebellion of 1917-1919. The Kuki rebellion might be a ploy of British India to create a Christian state in West-South East Asia. Robert Reid accepted the fact that Enjakhup was the brain of kuki rebellion of 1917-1919.

Enjakhup was a Sepoy of British Naga Hills Battalion and he reported to his British officer after the end of rebellion that he minimises the causality of British official and soldiers and British assets. ${ }^{15}$ And this hold to be truth as only four British India Army Officers and 64 sepoys were killed and only 154 British India Army were wounded (two personal of British origin got killed) in the whole sage of alleged Kuki Rebellion. ${ }^{16}$ Lal Dena in his book History of Modern Manipur (1826-1949) recorded that 39 Kabui villages were raided and burned, 278 villagers lost their lives many were gone missing as a result of Kuki Rebellion. ${ }^{17}$ Gangmumei Kamei in his book The History of Zeliangrong Nagas- From Makhel to Rani wrote that by the time of Kuki rebellion, Kuki already adopt the used of guns and canons in place of bow and arrows. At that time, many other communities' men were send to France as part of "Labour Corps" due to the World War 1 was going on. Kabui, Liangmai, Tangkhul were face the rages of Kuki Rebellion. ${ }^{18}$ Richard Kamei in his article "To bridge the divide in Manipur, the effects of a long cycle of violence should be accepted" that published by Indian Express on 17 November 2019 concluded that the British used the Kukis from 1840s-1930s to defeat other native communities in the Northeast India. ${ }^{19}$ Question like why only a total of 64 British Armed Force were killed and more than 248 villagers of other communities were killed, what was the purpose of burning of 39 Kabui villages in so called Kuki Rebellion against the British Empire are usually probed. Similarly in Kuki Rebellion from where the Kuki gets the 'guns and bullets' is a serious question as Guns or other weapons were under administration of Political Agent in name Governor of Assam in Manipur. Furthermore, not even a single licence was issue after the 1891 AngloManipur War. ${ }^{20}$

During the Kuki rebellion, in Middle East, British Empire promise the Jews for a Homeland to be craft out of Palestine ${ }^{21}$ as part of British Empire's Geo-politics. Under which the Jews community helps the British action in Europe against Germany and Central Powers and against Ottoman Empire in Middle East. One theory about the lineage of Kuki is that they are also considered to be one of Lost Tribe of Jews, the Bnei Menashe and an offer of British to Kuki i.e.,

${ }^{15}$ P.Chingkhei, Observation on the leaders and an "adventurer" in Anglo-Kuki War (1917-1919). Retrieved from Imphal Times: https://www.imphaltimes.com/guest-column/item/19152-observation-on-the-leaders-and-anadventurer-in-anglo-kuki-war-1917-1919 on 13 November 2020

${ }_{16}$ D.M. Kipgen, The great Kuki rebellion of 1917-19: Its real significances. Retrieved from The Sangai Express: http://epao.net/epSubPageExtractor.asp?src=manipur.History_of_Manipur.The great_Kuki_rebellion_of_1917-19, on October 2015

${ }^{17}$ L.Dena, History of Modern Manipur (1826-1949). New Delhi: Orbit Publishers-Distributors, 1991,p.56

18 G.Kamei, The History of Zeliangrong Nagas: From Makhel to Rani Gaidinliu. Gauhati: Spectrum Publications 2004,p.14

19 R.Kamei, To bridge the divide in Manipur, the effects of a long cycle of violence should be accepted. Retrieved from Indian Express: https://indianexpress.com/article/express-sunday-eye/the-fire-last-time-6119649/ on 17 November 2019

${ }^{20}$ Op.Cit., Chisti ,p.112

${ }^{21}$ M.Yapp, The Making of the modern Near East, 1792-1923. London, New York: Longman, 1987, p.290 
Jews to provide a homeland is very much possible. It is highly possible the British used the Kuki to create unrest in hills of Manipur to blame the King of Manipur and deprive its right to rule over his own land and right to arm itself. According to Major-General James Johnstone, kukis were first heard in Manipur between 1830-1840s; Colonial McCulloch the then Political Agent of British India Empire's to Manipur, provided them land in different parts of Manipur, allocated duties to kuki's Chiefs, he loans and gives them money and some were inducted as irregular troops of British India Army. ${ }^{22}$ In the article "The Aboriginal Tribes of Manipur" by Dr. George Watt, wrote, "The last great race of invaders and conquerors who entered Manipur was the Kukies or Lushais" he also penned Manipuris as a mixture of Naga and old Kukis. He also points out that the very existence of new kukis was the gift of Colonel McCulloch the then British Political Agent to Manipur. ${ }^{23}$

But the facts remain that the Maharaja of Manipur got no seat in the Chamber of Princes citing it as he have no sovereignty over its own land, finance, security, etc. and also on the ground that the Kingdom of Manipur is very poor. Thus, it can be conclude that the other Kings did not consider the Maharaja of Manipur as equal in British India Empire. Among its peers the Maharaja of Manipur was consider as a minion king who deserved no seat among them even if the Maharaja of Manipur got the privilege of Eleven Gun Salute.

On eve of Second World War, the Maharaja of Manipur was king for only religious ceremonies, as he holds no authority on matter of the security of state and its people as this fell at the hands of British India Empire. Finance, and administration of its 90 per cent of the land control by the Political Agent of British India Empire, even the day-to-day religious activities was perform by Hindu Brahma Sabha in Valley and by American Baptist Church in the hills. The Darbar was also under the absolute control of Political Agent of British India Empire. Therefore, public started dealing directly with the British and its agent like on matter of 'Chaktanba', nupilan, etc. When the Second World War reached Manipur, even if the Maharaja support the British India Empire but many of his subject support the Japanese Force. ${ }^{24}$ During the Second Word War as battlefield between the Allied Forces and Japanese Army, faceoff devastated the Kingdom of Manipur.

The British India Empire force the Maharaja of Manipur to organise cultural shows like of Ras lila and traditional dances to entertain the British India Army and Allied Forces when the State face shortages of foods for its citizens, inflation, cholera, and other disease. ${ }^{25}$ This may be the reason that political leader like Hijam Irabot revolt against the Maharaja of Manipur. Due to Meitei Tribe, culture having a very conservative view on sexual stories of comfort women were erase from the memory of the society and history. It is a general fact wherever an external military stations in a foreign land the stories of unfortunate comfort women is always associated even in today's world and the kingdom of Manipur cannot be an exception in such case.

\footnotetext{
${ }^{22}$ Op.Cit., Johnstone

${ }^{23}$ G. Watt, The Aboriginal Tribes of Manipur. The Journal of the Anthropological Institute of Great Britain and Ireland, 1887 , vol. 16, 346-370

${ }^{24}$ I. Chakravarty, (03 December 2017) As Manipur recovers its World War II past, it digs into both Japanese and British version of events. Retrieved from Scroll: https://scroll.in/article/859171/as-manipur-recovers-its-worldwar-ii-past-it-digs-into-both-japanese-and-british-version-of-events. On 15 June 2019

${ }^{25}$ S. Bhattacharji, Manipur and World War II: (In verse), With a Glimpse of the World: An epic poen by Sanasam Gourhari Singh, Kyoto: Ryukoku University, 2014.pp.7-8
} 
On 14 August 1947, the British left the Kingdom of Manipur; and Kingdom of Manipur proclaim itself as independent 'Democratic Constitutional Monarchic State'; and hold election and form an Assembly of elected representatives. The mighty Dominion of India (later Republic of India) the successor of British India Empire got eyes on Kingdom of Manipur and requested the Maharaja of Manipur for a talk in Shillong the then Capital of Assam- Dominion of India. When the Maharaja of Manipur got there, he was place in house arrest. He was threaten to sign the Merger Agreement with the Dominion of India or face an Invasion. When the Maharaja of Manipur at first denied signing such an agreement, the Governor of Assam seeks permission from Delhi for invasion. ${ }^{26}$ To that the then Deputy Prime Minister of Dominion of India, Sardar Patel responded "Isn't there a brigadier in Shillong?"27 May possibly be considering the welfare of his people the Maharaja of Manipur signed the Merger Agreement on 29 September 1949, two years after having a democratic elected government. On that night, a battalion of the Indian Army stormed the Palace to secured India's position and hosted Indian Tricolour as symbol of conquering of Kingdom of Manipur. There is saying in International Relations i.e., "Might is always right".

The Commander of Indian Army that stormed the Palace on that faithful night Major-General Rawal Amar Singh was latter appointed as Chief Commissioner of Dominion of India and he announced that all those who refused the annexation of kingdom of Manipur by Dominion of India are "Communist" and will be penalise on 15 October 1949. This shows that Dominion of India after the era of British give no regards to the Maharaja of Manipur. Again, against the term of Merger Agreement, the Government of Republic of India in 1971 cease to recognise the Maharaja of Manipur even as a nominal head of a once independent kingdom.

\section{Status of Maharaja of Manipur in Present Days}

The Print in its news article of 27 June 2020, reported that Leishemba Sanajaoba as one of the poorest Member of Parliament (MP) in India and this financially poor MP happen to be the Maharaja of Manipur. ${ }^{28}$ This current MP and Titular King have no hype air in his nature and very down to earth nature human being who is a pacifist and a real stateman working for peaceful coexistence and development. For him he always maintains that other communities of Manipur that already listed in Scheduled Tribe list are brother and sister community of Meitei. He feels that Meitei should be in the Scheduled Tribe List of India with consideration of many factors associating and hope it will bring a positive impact in conflict ridden poor state of Manipur. ${ }^{29}$

Even community of Tiprasa which Sir Bir Bikram Kishore Manikya Deb Barman, Maharaja of Tripura and Bhutia which Sir Tashi Namgyal, King of Sikkim belong both in Scheduled tribe list of India. Both Sir Tashi Namgyal, King of Sikkim and Sir Bir Bikram Kishore Manikya Deb

${ }^{26}$ K. Sanatomba, Polemics of the Manipur Merger Agreement. In A. Noni, \& K. Sanatomba, Colonialism and Resistance: Society and State in Manipur, Oxon: Routledge, 2016, pp.206-217

27 S. Baruah, (2001, June 01). Generals as Governors. Retrieved from Himal Southasian: http://www.himalma.com/generals-as-governors/. On 25 January 2019

${ }_{28}$ Manipur's titular king is the poorest among Rajya Sabha's 62 new MPs. (2020, June 27). Retrieved from The Print: https://theprint.in/neye/manipurs-titular-king-is-poorest-among-rajya-sabhas-62-new-mps/449728/, on 12 August 2020

${ }^{29}$ Sangai express. (2021, April 18). Personally support ST status for Meiteis: RS MP Titular king calls for peaceful co-existence. Retrieved from E-pao: http://e-pao.net/GP.asp?src=3..190421. On April 21 
Barman, Maharaja of Tripura were member of reputed exclusive club called "Chamber of Princes" in which member are of only high-status kings of British India. A club where the Maharaja of Manipur never become a member despite many applications and requests.

Here another important point to ponder is that a student's organisation like ATSUM (of highly Advance Christian Communities) which, is notorious for hampering India's development by conducting many economic blockades, roadblocks, bans, burning vehicles, etc. in highways from ages opposed the democratic right of Meitei Tribe based on their assumptions that Meitei Tribe used to have a kingdom and have a long written history and threaten to enact violence if Meitei tribe is listed in Scheduled Tribe list. ${ }^{30}$ Another student's organisation called AMSU (All Manipur Students Union) reputed as moral police, opposed the proposal of Meitei Tribe to be included in Scheduled Tribe list of India on their potential communal violence due it. Oinam and Oinam expressed their wonders on such opposition and claims in their articles "Understanding the mechanism of tribal community inclusion to Scheduled Tribe list in India: Meitei Tribe plea". ${ }^{31}$ Are these student organisations really a student organisation or some deviant groups who are eager to enact communal violence to prove itself true as nature of narcissist group? Therefore, question arises why and how an inclusion of poor, small community in Scheduled Tribe list will bring communal violence.

Academic like Lam Khan Piang in his article "Moving Backward: Meitei's Demand for Scheduled Tribe Status" holds the view that Meitei Tribe should not be in Scheduled Tribe list of India as Meitei Language is in $8^{\text {th }}$ Scheduled of India. ${ }^{32}$ However, the things are that a language in eighth Scheduled has nothing to do with Scheduled Tribe list of India. Bodo and Santal (Santali) are in Scheduled Tribe list of India and its language are in eighth Scheduled Tribe list of India. Another Academic known as Thonkholal Haokip in his article "The Politics of Scheduled Tribe Status in Manipur" concluded that Meitei Tribe cannot be in Scheduled Tribe list of India as Meitei Tribe follows Hinduism and strongly suggested only Christians should be in Scheduled Tribe list of India. ${ }^{33}$ However, the fact is that Republic of India is a secular country; one's individual practice of religion is one's personal choice and right which is guarantee by Supreme Court and Constitution of India. Here one may wonder why these academics express their viewpoints in writing. Probably just to attract some citation of their work, which in turn brings a relevance to their existence as academic.

Oinam and Oinam also deduct from Reserved Bank of India report that Meitei Tribe is poorest community in urban/semi-urban areas of India. ${ }^{34}$ The people are poor and so is the King himself. In a market-based economic society like of India poor are generally look down and have minimum social status.

\footnotetext{
${ }^{30}$ Newmai News Network. (2019, January 28). ATSUM lines up protests against ST demand of STDCM. Retrieved from E-Pao: http://e-pao.net/GP.asp?src=16..290119. On February 2019

31 O.T. Khumancha, \& Khumancha, O. G. Understanding the mechanism of tribal community inclusion to Scheduled Tribe List in India: Meitei Tribe plea. International Research Journal of Multidisciplinary Studies, October 2020, vol. 6, Issue 10, 1-7

${ }^{32}$ L.L.Piang, Moving Backward: Meitei's Demand for Scheduled Tribe Status. Economic \& Political Weekly, 12 April 2014, Vol. 49, Issue No. 15

${ }^{33}$ T.Haokip, The Politics of Scheduled Tribe Status in Manipur. Society and Culture in South Asia, 2015.pp. 82-89

34 O.T. Khumancha, \& Khumancha, O. G. The missing Meitei Tribe nationalism in Western Southeast Asia (WESEA). Manipur Chronicles, 30 August 2020, Vol. IX, Issue 70, p. 3
} 
At present Meitei Tribes lives in small ghetto known as Imphal Valley of 1864.44 sq. km., which is just $8.3 \%$ of total area of Manipur. Furthermore, this area is an open area where everyone can buy and own without exception. Indian's Law and Acts barred the poor, weak, marginalised Meitei Tribe to settle outside the Imphal Valley. Meitei Tribe is of just 12 lacs population as according to Register General of India reports. Any member of this tribe holds no significant post of any Indian Administrative Service. Meitei language is not allowed to learn in State of Assam, Bangladesh, and Myanmar. In Assam and Bangladesh, people are voicing the government to allow them to learn their mother languages. Moreover, in Myanmar the language, culture all seems lost, and they just remember they are Meitei tribe. This indicates the tribe is on the verge of extinction.

\section{CONCLUSION}

Based on the above information we can be conclude that even before the arrival of British in Manipur its Meitei tribe were backward and unorganised. The Manipur wannabe rulers fought among themselves and this must have ruin the economy of the society. Such society or community cannot develop or advance in any practical real sense. This clears one statement that Meitei Tribe is backward community from the very beginning.

British India Empire at one time designate Manipur as its protectorate without any opposition from ruling class of Meitei Tribe and place under a Political Agent. Even then, without consulting the Maharaja of Manipur, British sliced a huge chunk of territory and bestowed it upon Burmese Empire. The British does not even feel necessary to take Manipur's concern on such topic; this show British have overwhelming supremacy over Manipur and its people. Later, the British defeated the Manipur and inducted as a Princely State of British India Empire. Nevertheless, when the "Chamber of Princes" was established, Manipur's Maharaja was refuse to a seat in that Chamber. The king of Tripuri Tribes was given a prestigious seat and so is the king of Bhutia and Lepcha Tribes were also given the prestigious seat in the Chamber. This indicates that Meitei Tribes and its Maharaja was not count worthy enough in front of British and eyes of other Indian kings.

At Present according to RBI, Meitei tribe is also one of the poorest communities in India. Its population is diminishing over the years. The government of India or other authorities of the world do not recognise its religious practices. Meitei Tribe's Maharaja or King is poorest Member of Parliament in India. When the king is so underprivileged, it become obvious that the subjects are also poor. They are living at the mercy of advance Christian communities and rigid Government of India. Meitei Tribe was a backward community in the past and in the present also. It remain a backward community. It is high time to recognise them as Scheduled Tribe of India under the Indian Constitution with understanding of Supreme Court of India of indigenous people and to safeguard the ancient relics called Meitei Tribe with its Maharaja. 


\section{REFERENCES}

Allan, J., Haig, W., \& Dodwell, H. The Cambridge Shorter History of India. Cambridge: Cambridge University.1969

Baruah, S. (2001, June 01). Generals as Governors. Retrieved from Himal Southasian : http://www.himalma.com/generals-as-governors/

Bhattacharji, S. Manipur and World War II: (In verse), With a Glimpse of the World: An epic poen by Sanasam Gourhari Singh. Kyoto: Ryukoku University,2014

Chakravarty, I. (2017, December 03). As Manipur recovers its World War II past, it digs into both Japanese and British version of events. Retrieved from Scroll: https://scroll.in/article/859171/as-manipur-recovers-its-world-war-ii-past-it-digs-into-bothjapanese-and-british-version-of-events

Chingkhei, P. (2020, November 13). Observation on the leaders and an "adventurer" in AngloKuki War (1917-1919). Retrieved from Imphal Times: https://www.imphaltimes.com/guestcolumn/item/19152-observation-on-the-leaders-and-an-adventurer-in-anglo-kuki-war-19171919

Chisti, S. Political Development in Manipur, 1919-1949. Aligarh: Aligarh Muslim University, 1979

Dena, L. History of Modern Manipur (1826-1949). New Delhi: Orbit PublishersDistributors, 1991

Grimwood, E. S. My Three Years in Manipur and Escape from the Recent Mutiny. London: Richard Bentley,1891

Haokip, T. The Politics of Scheduled Tribe Status in Manipur. Society and Culture in South Asia, 2015, 82-89

Johnstone, M. G. My Experiences in Manipur and the Naga Hills. London: Sampson Low, Marston and Company Limited,1896

Kamei, G. The History of Zeliangrong Nagas: From Makhel to Rani Gaidinliu. Gauhati: Spectrum Publications, 2004

Kamei, R. (2019, November 17). To bridge the divide in Manipur, the effects of a long cycle of violence should be accepted. Retrieved from Indian Express: https://indianexpress.com/article/express-sunday-eye/the-fire-last-time-6119649/

Khumancha, O. T., \& Khumancha, O. G. Understanding the mechanism of tribal community inclusion to Scheduled Tribe List in India: Meitei Tribe plea. International Research Journal of Multidisciplinary Studies, October 2020 ,vol. 6, Issue 10, 1-7 
Khumancha, O. T., \& Khumancha, O. G. The missing Meitei Tribe nationalism in Western Southeast Asia (WESEA). Manipur Chronicles,30 August 2020, Vol IX, Issue 70

Kipgen, D. M. (2015). The great Kuki rebellion of 1917-19: Its real significances. Retrieved from The Sangai http://epao.net/epSubPageExtractor.asp?src=manipur.History_of_Manipur.The_great_Kuki_rebellio n_of_1917-19

Manipur: Titular king Leishemba Sanajaoba makes maiden visit to Ukhrul as MP. (2020, August 21). East Mojo, pp. https://www.eastmojo.com/news/2020/08/21/manipur-titular-kingleishemba-sanajaoba-makes-maiden-visit-to-ukhrul-as-mp/.

Manipur's titular king is the poorest among Rajya Sabha's 62 new MPs. (2020, June 27). Retrieved from The Print: https://theprint.in/neye/manipurs-titular-king-is-poorest-amongrajya-sabhas-62-new-mps/449728/

McCulloch.W. Account of the Valley of Munnipore and the Hill tribes: with a comparative vocabulary of the Munnipore and other languages" (1859) New Delhi : Akansha Publishing House, 2016

NewmaiNewsNetwork. (2019, January 28). ATSUM lines up protests against ST demand of STDCM. Retrieved from E-Pao: http://e-pao.net/GP.asp?src=16..290119.jan19

Piang, L. L. Moving Backward: Meitei's Demand for Scheduled Tribe Status. Economic \& Political Weekly, 12 April 2014,Vol. 49, Issue No. 15.

Ramusack, B. N. The Princes of India in the Twilight of Empire: Dissolution of a Patron-client System, 1914-1939. Ohio: Ohio State University Press, 1978

Sanatomba, K. Polemics of the Manipur Merger Agreement. In A. Noni, \& K. Sanatomba, Colonialism and Resistance: Society and State in Manipur (pp. 206-217). Oxon: Routledge, 2016

Sangaiexpress. (2021, April 18). Personally support ST status for Meiteis: RS MP Titular king calls for peaceful co-existence. Retrieved from E-pao: http://epao.net/GP.asp?src=3..190421.apr21

Watt, G. The Aboriginal Tribes of Manipur. The Journal of the Anthropological Institute of Great Britain and Ireland,1887, vol. 16, 346-370.

Yapp, M. The Making of the modern Near East, 1792-1923. London, New York: Longman,1987 